\title{
PHYSICO-CHEMICAL PARAMETER VARIABILITY RELATIVE TO SEASONAL DYNAMICS AND COMMUNITY STRUCTURE OF PLANKTON IN THE BOUKOURDANE LAKE DAM (ALGERIA)
}

\author{
BRAHIM ERRAHMANI, M. ${ }^{12^{*}}-$ HAMAIDI-CHERGUI, F. ${ }^{2}$ - HAMAIDI, M. S. ${ }^{2}$ \\ ${ }^{1}$ Department of Chemistry, Faculty of Sciences, Blida 1 University, Algeria. \\ (phone/fax: +213-25-433-642) \\ ${ }^{2}$ Department of Biology, Faculty of Natural and Life Sciences, Blida 1 University, Algeria. \\ (phone/fax: +213-25-434-803) \\ *Corresponding author \\ e-mail:m.brahim.errahmani@univ-blida.dz \\ (Received 22 $2^{\text {nd }}$ Nov 2014; accepted $15^{\text {th }}$ Apr 2015)
}

\begin{abstract}
The impact of seasonal variations in the water physico-chemical parameters on the zooplankton and phytoplankton composition was investigated in the Boukourdane reservoir (Tipaza, Algeria) over two years (April 2005-March 2007). High levels of nitrites were observed during the cold seasons, and the phosphate levels were higher in summer with a very high $\mathrm{NO}_{3} / \mathrm{PO}_{4}{ }^{3-}$ ratio $(>30)$ in winter. A significant increase in the level of chlorophyll $a(\mathrm{Chl} a)$ was observed in spring. The relative standard deviations (RSDs) highlighted a large variability during the warm seasons, especially for nitrites, nitrates, phosphates and ammonia. A great species diversity was observed (rotifers: 79, copepods: 13, and phytoplankton: 83). The weighted averages of the species enabled us to determine the optimal values of their physico-chemical parameters, as elevated temperatures for Bacillariophyta and Pyrrhophyta or high concentrations of chlorophyll $a$ for Charophyta. The zooplankton was more prevalent during the spring and appeared to be correlated with sulfates and electrical conductivity. A redundancy analysis (RDA) corroborated the previous results and explained $84.1 \%$ of the total variance. This analysis highlights the influence of some of the environmental variables on the seasonal distribution of plankton, characterized by a high profusion in spring and scarcity in autumn and winter.
\end{abstract}

Keywords: environmental parameters, zooplankton, RDA, correlations, weighted average

\section{Introduction}

Dams have been used for thousands of years to regulate river flows and ensure an adequate supply of water during dry periods (McCartney et al., 2001). The steadily increasing demand for water in recent decades poses various problems, both qualitative and quantitative (Ramdani et al., 2012). Changes in land use and management practices can have a considerable impact on water quality parameters (Brainwood et al., 2004). Due to the tremendous development of industry and agriculture, the disposal of untreated public sewage water, and agricultural runoff, the water quality and its biotic resources are in continuous deterioration (Venkatesan, 2007; Elmaci et al., 2008).

Through biomonitoring, the environmental quality of a given site can be judged from its species assemblages, based on knowledge of environment-biota relationships (Pilière et al., 2014).

Knowledge of the characteristics of a habitat, its species composition and the physicochemical and biological factors that directly or indirectly affect the inhabitants are essential for a proper appraisal of the ecology of the aquatic animal species.

Zooplankton and phytoplankton have recently been used as indicators to observe and understand changes in an ecosystem because they seem to be strongly influenced by climatic 
features (Beaugrand et al., 2000; Al-Ghanim, 2012). Telesh (2004) stated that plankton is an important ecosystem component that responds to ecosystem alterations rather rapidly.

The ecology of aquatic environments has been widely studied elsewhere in the world, but very few limnological studies have been made on the freshwater ecosystem of Algeria (Cherbi et al., 2008; Hamaidi et al., 2008, 2009, 2010; Chaib et al., 2011; Hamaidi-Chergui and Hamaidi, 2013; Hamaidi-Chergui et al., 2013). The aim of this study was to establish relationships between the seasonal variations of environmental and biological variables and to contribute to an understanding of the ecology of the copepod, rotifer and phytoplankton taxonomic composition in the Boukourdane Lake Dam.

\section{Material and methods}

\section{Area of study}

The Boukourdane rockfill dam (Fig. 1) is located in the northwest of Mitidja (Sidi Amar, $36^{\circ} 32^{\prime} 03^{\prime}{ }^{\prime} \mathrm{N} 02^{\circ} 18^{\prime} 18^{\prime}$ ' $\mathrm{E}$ ) and was constructed in 1985. It has a height of $74.4 \mathrm{~m}$ and a retained water volume of $97 \mathrm{hm}^{3}$. It receives water from the Menaceur and Fedjana rivers and is situated in a sub-humid climate region with $500 \mathrm{~mm}$ average pluviometry (Cherbi et al., 2008). It can be considered as a mid-size dam (Foum El Gueiss $0.43 \mathrm{hm}^{3}$, Beni Haroun $998 \mathrm{hm}^{3}$ ), and it supplies fresh water to Tipaza, Cherchell and the capital Algiers. Its waters are also used for irrigation of the western Mitidja perimeter.

\section{Physico-chemical analysis}

The water samples were collected between 9 and 11 a.m. from three sites of near surface water, three times per month between April 2005 and March 2007, and were then placed in polyethylene containers $(2 \mathrm{~L})$.

The $\mathrm{pH}$ and the electrical conductivity (EC) were measured in the field using a Hach sensION pH meter and a HD 3406.2 (Delta Ohm) conductivity meter, respectively.

Nitrate, nitrite, chloride and phosphate were analysed according to the standard methods described by APHA (1998) and Rodier (1997).

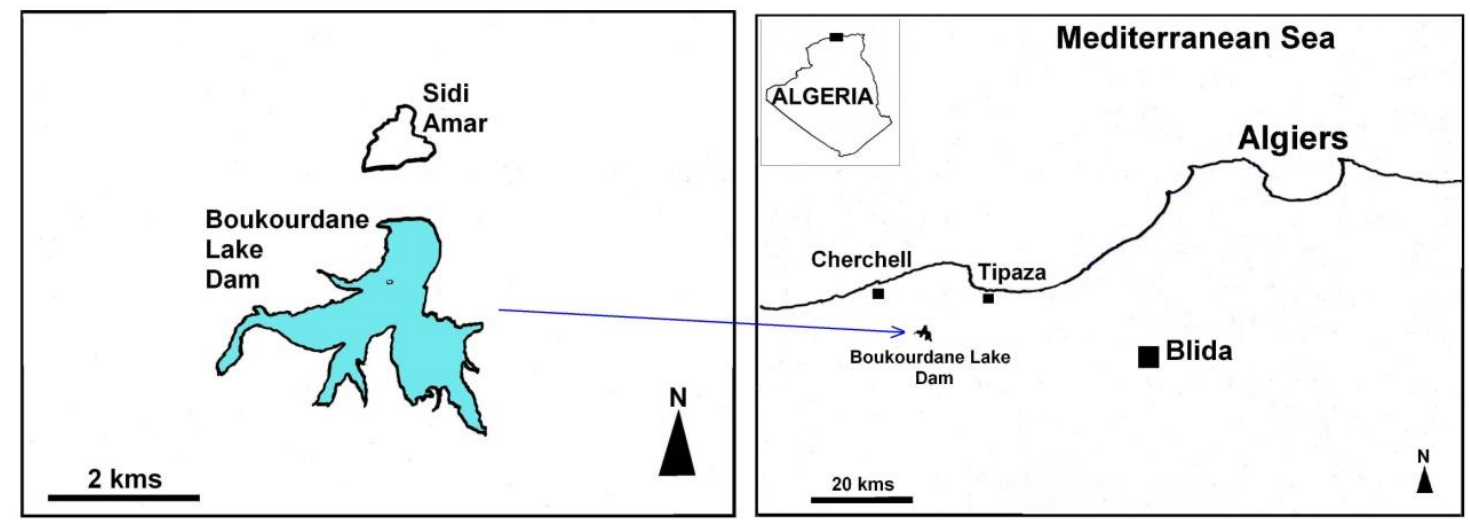

Figure 1. Location of the Boukourdane Lake Dam (Algeria).

The calcium and magnesium concentrations were determined using atomic absorbance spectrophotometry (AAS), and the sodium was measured using flame photometry. The permanganate oxidation method was used to determine organic matter. 
Sub-samples were filtered (Whatman GF/C membranes) and used to quantify Chl $a$ concentrations using spectrofluorimetry.

\section{Plankton identification and enumeration}

Sampling was carried out using a plankton net of $105-\mu \mathrm{m}$ mesh size. One litre of sub-surface collected water was immediately preserved with $5 \mathrm{~mL}$ of $4 \%$ formalin solution and then kept for $24 \mathrm{~h}$ undisturbed to allow the sedimentation of the plankton. The supernatant was pipetted out, and the sample was concentrated to $10 \mathrm{~mL}$.

The drop count method (Trivedy and Goel, 1984) was used for the quantitative estimation of the phytoplankton and zooplankton.

The phytoplankton was identified in accordance with standard methods (Bourelly 1966, 1968, 1970; Sournia, 1968; Compère, 1974, 1975a, 1975b, 1977, 1991, 1992, 2001; Komarek and Anagnostidis, 1986, 1989; Anagnostidis and Komarek 1988, 1990) and more specific literature.

The zooplankton groups were identified according to the literature on copepods (Dussart and Defaye, 1985, 2001; Einsle, 1996; Karaytug, 1999) and rotifers (Pourriot and Francez, 1986; Nogrady et al., 1993).

\section{Data treatment and statistical analysis}

The data distributions were first tested for the normality and the homogeneity of variances using the Kolmogorov-Smirnov and Levene tests, respectively. The Pearson's correlation coefficients were determined to identify relationships among the environmental variables and between these variables and species abundances. The sampling variability was estimated by calculating the "relative standard deviation" (RSD), also known as the "coefficient of variation".

The seasonal variations (spring, summer, autumn and winter) were compared using one-way ANOVA, and the significant differences were highlighted using the NewmanKeuls or Tukey post hoc tests. When the assumptions of the normality and homogeneity of variances were violated, the alternative Kruskal-Wallis ANOVA on ranks with multiple comparisons on groups was performed. The analysis was performed using Statistica 10 (Statsoft Inc, Tulsa, OK, USA), and the results are given as the mean \pm SE (SE: standard error of mean).

Each species has its own optimal environmental conditions for proliferation. An estimate of this optimum value of each parameter for each species was made by calculating the weighted average

$$
\mathrm{WA}(\mathrm{Sp})=\sum_{\mathrm{i}}(\text { Env })_{\mathrm{i}}(\text { Abund })_{\mathrm{i}} / \sum_{\mathrm{i}}(\text { Abund })_{\mathrm{i}}
$$

where $(\text { Env })_{i}$ is the value of the environmental variable in the $i^{\text {th }}$ sample and $(\text { Abund })_{i}$ is the abundance of the species in the same sample (Leps and Smilauer, 2003).

The general relationships between the physico-chemical variables and taxa were studied using the redundancy analysis (RDA) under Canoco 4.5 for Windows (ter Braak and Smilauer, 2002). This technique can summarize the relations between response variables and several predictors, the biological species and environmental variables, respectively (Leps and Smilauer, 2003). 


\section{Results}

\section{Physico-chemical variables}

The seasonal variations of the physico-chemical variables of water over the two years of the experiment are given in Table 1.

Table 1. Seasonal variations of physico-chemical variables in the Boukourdane Lake Dam (EC: Electrical conductivity; DO: Dissolved oxygen; Org. m.: Organic matter; Ch.a:

Chlorophyll a, AG: Algerian guidelines). Data are given as the mean $\pm S E$

\begin{tabular}{|c|c|c|c|c|c|c|c|c|}
\hline & $\mathbf{T}\left({ }^{\circ} \mathbf{C}\right)$ & pH & $\underset{\left(\mu \text { S.cm }^{-1}\right)}{\mathbf{E C}}$ & $\begin{array}{l}\text { DO } \\
(\%)\end{array}$ & $\begin{array}{l}\text { Nitrates } \\
\left(\text { mg.L }^{-1}\right)\end{array}$ & $\begin{array}{l}\text { Nitrites } \\
\left(\mathbf{m g} . L^{-1}\right)\end{array}$ & $\begin{array}{l}\text { Sulfates } \\
\left(\text { mg.L }^{-1}\right)\end{array}$ & $\underset{\left(\mathrm{mg} . \mathrm{L}^{-1}\right)}{\text { Ammonia }}$ \\
\hline Spring & $21.2 \pm 0.6$ & $7.8 \pm 0.1$ & $803 \pm 31$ & $91.9 \pm 2.2$ & $4.5 \pm 1.1$ & $0.024 \pm 0.011$ & $150.7 \pm 7.2$ & $0.034 \pm 0.034$ \\
\hline Range & $18.5-23.0$ & 7.6-8.1 & $710-900$ & $85-98$ & $2.5-8.0$ & $0-0.068$ & $131-178$ & $0-0.20$ \\
\hline Summer & $27.2 \pm 0.8$ & $7.5 \pm 0.3$ & $735 \pm 25$ & $95.8 \pm 8.8$ & $3.4 \pm 1.7$ & $0.023 \pm 0.015$ & $146.8 \pm 5.7$ & $0.023 \pm 0.016$ \\
\hline Range & $25-30$ & $6.3-8.0$ & $690-840$ & $76-127$ & $0-11$ & $0-0.09$ & $130-164$ & $0-0.10$ \\
\hline Autumn & $16.8 \pm 1.1$ & $7.5 \pm 0.1$ & $655 \pm 12$ & $75.0 \pm 9.3$ & $2.9 \pm 1.7$ & $0.038 \pm 0.017$ & $127.5 \pm 1.8$ & $0.015 \pm 0.007$ \\
\hline Range & $13.7-20.3$ & 7.0-7.8 & $600-680$ & $44-111$ & $0.30-11.00$ & $0-0.112$ & $122-135$ & $0-0.042$ \\
\hline Winter & $14.3 \pm 0.7$ & $7.7 \pm 0.1$ & $600 \pm 11$ & $83.6 \pm 6.9$ & $4.1 \pm 1.2$ & $0.307 \pm 0.134$ & $130.2 \pm 2.2$ & $0.102 \pm 0.045$ \\
\hline Range & $12.8-16.4$ & 7.5-7.9 & $580-650$ & $63-104$ & $0-8.00$ & $0-0.817$ & $125-139$ & $0-0.300$ \\
\hline $\mathrm{p}$ & & 0.29 & 0.0002 & 0.25 & 0.88 & 0.019 & 0.003 & 0.18 \\
\hline 2-years means & $19.9 \pm 1.1$ & $7.6 \pm 0.1$ & $698 \pm 18$ & $85.9 \pm 3.9$ & $3.7 \pm 0.7$ & $0.098 \pm 0.041$ & $138.8 \pm 3.1$ & $0.043 \pm 0.016$ \\
\hline $\mathrm{AG}$ & 30 & $6.5-8.5$ & 2800 & & 50 & 0.1 & & 0.5 \\
\hline WHO standards & $25-30$ & $6.5-8.5$ & $180-1000$ & & 50 & $\leq 0.1$ & & $\leq 0.1$ \\
\hline & \multicolumn{2}{|c|}{$\begin{array}{l}\text { Phosphates } \\
\left(\text { mg.L }{ }^{-1}\right)\end{array}$} & $\begin{array}{l}\text { Sodium } \\
\left(\text { mg. } \mathbf{L}^{-1}\right)\end{array}$ & $\begin{array}{l}\text { Chloride } \\
\left(\text { mg.L }^{-1}\right)\end{array}$ & $\begin{array}{l}\text { Calcium } \\
\left(\text { mg. }^{-1}\right)\end{array}$ & $\underset{\left(\text { mg.L } .^{-1}\right)}{\text { Magnesium }}$ & $\begin{array}{l}\text { Org. m. } \\
(\text { mg.L }\end{array}$ & $\underset{\left(\mu \mathrm{g} . \mathrm{L}^{-1}\right)}{\mathrm{Chl} a}$ \\
\hline Spring & \multicolumn{2}{|c|}{$0.24 \pm 0.24$} & $47.5 \pm 3.0$ & $67.3 \pm 6.2$ & $75.7 \pm 2.7$ & $31.5 \pm 2.0$ & $6.18 \pm 1.49$ & $7.72 \pm 1.65$ \\
\hline Range & \multicolumn{2}{|c|}{$0-1.47$} & $40-57$ & 41.84 & $69-87$ & $24-37$ & $3.2-13.3$ & $4.5-13.3$ \\
\hline Summer & \multicolumn{2}{|c|}{$0.55 \pm 0.34$} & $41.3 \pm 2.5$ & $76.8 \pm 4.1$ & $67.7 \pm 3.3$ & $34.4 \pm 2.3$ & $4.18 \pm 0.62$ & $5.72 \pm 0.96$ \\
\hline Range & \multicolumn{2}{|c|}{$0-2.14$} & $31-49$ & $58-86$ & $54-76$ & $30-43$ & $2.3-6.1$ & $2.30-8.54$ \\
\hline Autumn & \multicolumn{2}{|c|}{$0.34 \pm 0.17$} & $42.8 \pm 3.2$ & $74.7 \pm 1.1$ & $67.5 \pm 0.7$ & & $3.62 \pm 0.43$ & $2.40 \pm 0.50$ \\
\hline Range & \multicolumn{2}{|c|}{$0-1.16$} & $35-52$ & $70-78$ & $66-70$ & & $2.00-4.60$ & $1.07-4.30$ \\
\hline Winter & \multicolumn{2}{|c|}{$0.13 \pm 0.11$} & $40.8 \pm 2.3$ & $69.7 \pm 0.6$ & $64.5 \pm 2.4$ & & $6.32 \pm 1.50$ & $3.10 \pm 0.98$ \\
\hline Range & \multicolumn{2}{|c|}{$0-0.67$} & $33-48$ & $68-72$ & $60-75$ & & $2.6-11.9$ & $0.12-5.40$ \\
\hline $\mathrm{p}$ & \multicolumn{2}{|c|}{0.64} & 0.33 & 0.11 & 0.029 & 0.37 & 0.24 & 0.017 \\
\hline 2-years means & \multicolumn{2}{|c|}{$0.32 \pm 0.11$} & $43.2 \pm 1.3$ & $72.1 \pm 1.9$ & $68.8 \pm 1.4$ & $32.8 \pm 1.5$ & $5.07 \pm 0.58$ & $4.74 \pm 0.68$ \\
\hline $\mathrm{AG}$ & \multicolumn{2}{|c|}{0.5} & 100 & 250 & 75 & 50 & & \\
\hline WHO standards & \multicolumn{2}{|c|}{0.2} & 150 & 250 & 200 & 50 & $<5$ & \\
\hline
\end{tabular}

The biennial average temperature was $19.9 \pm 1.1^{\circ} \mathrm{C}$, and the water $\mathrm{pH}$ fluctuated slightly between 7.5 and 7.8. The electrical conductivity (mean $698 \mu{\mathrm{S} . \mathrm{cm}^{-1}}^{\text {) }}$ was significantly higher in spring and summer $(\mathrm{p}<0.01)$.

Despite not significant variations, the nitrate concentration reached high values in spring and winter (2.9 to $\left.4.5 \mathrm{mg} . \mathrm{L}^{-1}\right)$. The nitrite concentration remained low throughout 
the year but increased sharply in winter to $0.31 \mathrm{mg} . \mathrm{L}^{-1}$ (three times the standard value). The phosphate level fluctuated between low levels in winter and high levels in summer, 0.13 and $0.55 \mathrm{mg} . \mathrm{L}^{-1}$, respectively.

The $\mathrm{NO}_{3}{ }^{-} / \mathrm{PO}_{4}{ }^{3-}$ ratio is an interesting parameter, sometimes used to identify the element that inhibits the development of phytoplankton. It was found to be very high in winter $(>30)$ and low in summer and autumn $(<10)$.

The seasonal average of ammonia remained under standard values, suggesting a low degree of sewage pollution in the lake, with the highest values recorded in winter and the lowest in summer and autumn. The sulfate level was significantly higher in spring and summer $\left(>145 \mathrm{mg} . \mathrm{L}^{-1}\right)$ but decreased in autumn and winter $\left(<128 \mathrm{mg} . \mathrm{L}^{-1}\right)$.

The level of sodium was found to be slightly higher during spring but otherwise moderate. The calcium level was significantly higher in spring $\left(75.7 \mathrm{mg} . \mathrm{L}^{-1}\right)$ and fell during winter to $64.5 \mathrm{mg} . \mathrm{L}^{-1}$, remaining at intermediate values during the rest of the year. The level of magnesium during spring and summer was found to be under standard limits.

Chl $a$ was significantly higher in spring $\left(7.72 \mu \mathrm{g} . \mathrm{L}^{-1}\right)$, remained at intermediate values in summer, and then fell under $3.2 \mu \mathrm{g} . \mathrm{L}^{-1}$ in autumn and winter. The variations in the organic matter content were not significant throughout the period of study (3.62 to $\left.6.32 \mathrm{mg} \cdot \mathrm{L}^{-1}\right)$.

\section{Relative standard deviation (RSD)}

Over a low concentration range, the variability is estimated as the average standard deviation of replicates, while over a high concentration range, the variability can be estimated as the average of the factor $\operatorname{RSD}=100 .(\sigma / \overline{\mathrm{x}})$, where $\sigma$ is the standard deviation and $\bar{x}$ the mean of the variable.

The extreme seasonal fluctuations of the environmental variables were identified through the factor RSD (Table 2).

Table 2. Extreme RSD (relative standard deviation in \%) of physico-chemical variables in the Boukourdane Lake Dam for the four seasons.

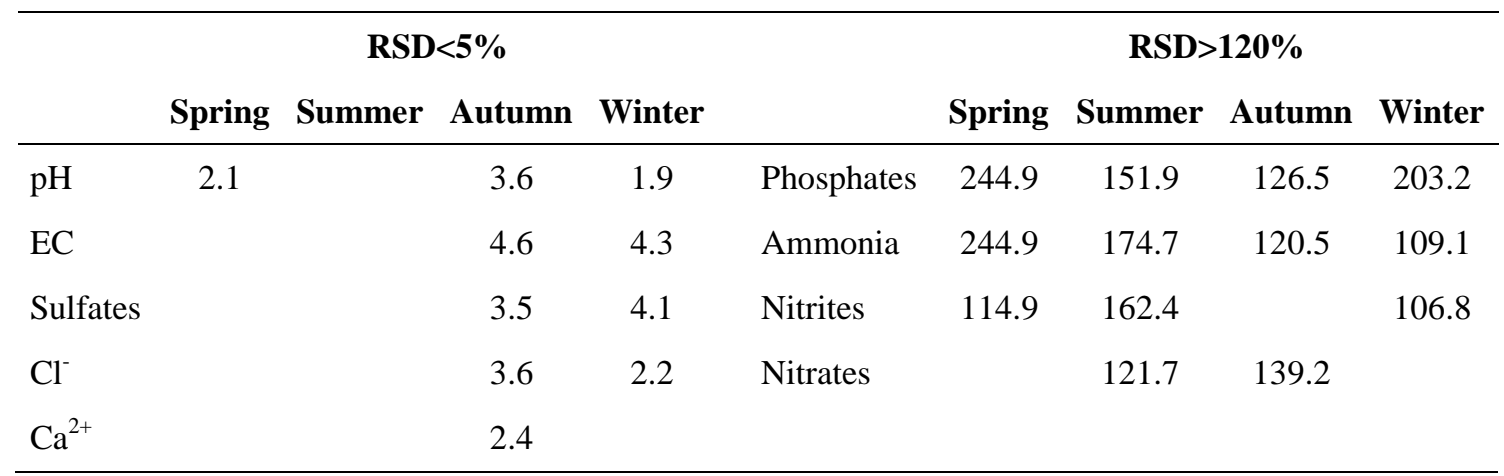

The variables of $\mathrm{pH}, \mathrm{EC}$, sulfates, chloride and calcium had the lowest variabilities, below 5\%, during the cold periods (autumn and winter), while the variables of phosphates, ammonia, nitrites and nitrates had the highest variabilities, over $120 \%$, mostly in summer. 


\section{Pearson's correlation coefficients}

When two variables are correlated, tracking one of them enables measuring the change in the other, reducing the experimental costs of physico-chemical monitoring.

The most significant positive correlations $(\mathrm{p}<0.01$, Table 3$)$ were observed between T, EC and $\mathrm{SO}_{4}{ }^{2-} ; \mathrm{EC}$ and $\mathrm{Ca}^{2+} ; \mathrm{pH}$ and $\mathrm{Na}^{+} ; \mathrm{NO}_{2}{ }^{-}$and $\mathrm{NH}_{4}{ }^{+}$; and $\mathrm{EC}$ and $\mathrm{Chl} a$.

The most significant negative correlations $(\mathrm{p}<0.01)$ were observed between the $\mathrm{pH}$ and $\mathrm{PO}_{4}{ }^{3-}, \mathrm{NH}_{4}{ }^{+}$and $\mathrm{Cl}^{-}$, and $\mathrm{PO}_{4}{ }^{3-}$ and $\mathrm{Cl}^{-}$.

Table 3. Pearson's correlation coefficients among environmental variables ( ${ }^{*} p<0.05$;

$\left.{ }^{* *} p<0.01 ;{ }^{* * * *} p<0.001\right)$

\begin{tabular}{|c|c|c|c|c|c|c|c|c|c|c|c|c|c|c|c|}
\hline & $\mathbf{T}$ & pH & EC & DO & $\mathrm{NO}_{3}^{-}$ & $\mathrm{NO}_{2}^{-}$ & $\mathrm{SO}_{4}{ }^{2-}$ & $\mathbf{N H}_{4}{ }^{+}$ & $\mathbf{P O}_{4}{ }^{3-}$ & $\mathrm{Na}^{+}$ & $\mathrm{Cl}^{-}$ & $\mathrm{Ca}^{2+}$ & $\mathbf{M g}^{2+}$ & Org $\mathbf{m}$ & Chl $a$ \\
\hline $\mathrm{T}$ & 1,00 & & & & & & & & & & & & & & \\
\hline $\mathrm{pH}$ & $-0,06$ & 1,00 & & & & & & & & & & & & & \\
\hline EC & $\mathbf{0 , 5 8 ^ { * * }}$ & 0,24 & 1,00 & & & & & & & & & & & & \\
\hline D.O. & 0.42 & 0,21 & 0,15 & 1,00 & & & & & & & & & & & \\
\hline $\mathrm{NO}_{3}^{-}$ & 0,04 & 0,36 & 0,11 & $0,54^{* *}$ & 1,00 & & & & & & & & & & \\
\hline $\mathrm{NO}_{2}^{-}$ & $-0,37$ & 0,13 & $-0,36$ & $-0,02$ & 0,17 & 1,00 & & & & & & & & & \\
\hline $\mathrm{SO}_{4}{ }^{2-}$ & $0,57^{* *}$ & 0,36 & $0,69^{* * * *}$ & 0,40 & 0,22 & $-0,22$ & 1,00 & & & & & & & & \\
\hline $\mathrm{NH}_{4}{ }^{+}$ & $-0,22$ & 0,05 & $-0,42^{*}$ & 0,18 & 0,10 & $0, \mathbf{5 3}^{* *}$ & $-0,30$ & 1,00 & & & & & & & \\
\hline $\mathrm{PO}_{4}{ }^{3-}$ & 0.28 & $-0,53^{* *}$ & $-0,09$ & $-0,24$ & $-0,40$ & $-0,08$ & $-0,22$ & 0,25 & 1,00 & & & & & & \\
\hline $\mathrm{Na}^{+}$ & $-0,01$ & $0,63^{* * * *}$ & $0,42^{*}$ & 0,37 & $0,42^{*}$ & $-0,06$ & 0,31 & $-0,04$ & $-0,37$ & 1,00 & & & & & \\
\hline $\mathrm{Cl}^{-}$ & 0,17 & 0,04 & 0,18 & 0,20 & 0,17 & $-0,04$ & 0,39 & $-0,52^{* * *}$ & $-0,59^{* * *}$ & 0,06 & 1,00 & & & & \\
\hline $\mathrm{Ca}^{2+}$ & 0,26 & 0,36 & $0,64^{* * * *}$ & 0,29 & 0,16 & $-0,22$ & $0,44^{*}$ & $-0,27$ & $-0,05$ & $0,46^{*}$ & 0,03 & 1,00 & & & \\
\hline $\mathrm{Mg}^{2+}$ & 0,28 & $-0,07$ & 0,20 & $-0,60$ & 0,37 & $0,61^{*}$ & $0,64^{*}$ & $-0,21$ & $-0,19$ & $-0,24$ & 0,48 & $-0,22$ & 1,00 & & \\
\hline Org. m. & -0.11 & 0,34 & 0,11 & $0,43^{*}$ & 0,19 & 0,34 & $-0,11$ & $0,47^{*}$ & $-0,28$ & $0,43^{*}$ & $-0,12$ & 0,22 & $-0,67^{*}$ & 1,00 & \\
\hline Chl $a$ & $0.43^{*}$ & 0,11 & $0,61^{* * a}$ & 0,13 & 0,10 & $-0,27$ & 0,31 & $-0,41^{*}$ & $-0,19$ & 0,16 & $-0,04$ & $0,44^{*}$ & $-0,20$ & 0,20 & 1,00 \\
\hline
\end{tabular}

\section{Plankton analysis, seasonal richness of copepods, rotifers and phytoplankton}

A total of 92 zooplankton species belonging to the two principal zooplankton groups (13 copepods and 79 rotifers) were found in the Boukourdane Lake Dam.

Some species of rotifers, including Polyarthra remata, Keratella quadrata quadrata, Lecane monostyla, Lecane luna, Testudinella patina patina, Brachionus quadridentatus quadridentatus and Asplanchna priodonta, occurred in most of the samples $(73.3 \%$ of the counted total).

The most prevalent species in spring were Keratella quadrata quadrata, Lecane monostyla, Lecane luna, Brachionus quadridentatus quadridentatus. Another species present in summer samples was Hexarthra fennica.

Polyarthra remata was present, especially in winter (53.0\%), together with Asplanchna priodonta; Testudinella patina patina and Filinia longiseta were found in autumn.

Only three species of copepods, namely Copidodiaptomus numidicus (calanoid, 32.2\%), Acanthocyclops trajani (cyclopoid, 14.8\%) and Eucyclops agiloides (cyclopoid, $11.6 \%$ ), were widespread and occurred in most of the samples.

Cyclops strenuus strenuus and Metacyclops minutus were also observed, but in smaller quantities. 
The average number of copepods (Fig. 2) was high in spring (median=251 ind. $\mathrm{L}^{-1}$ ) and summer (198 ind. $\mathrm{L}^{-1}$ ) but much lower in autumn (with a large variability) and winter $\left(<100\right.$ ind. $\left.L^{-1}\right)$.

Rotifers (Fig. 3) abounded in spring (median $=204$ ind. $\mathrm{L}^{-1}$ ), with a large variability during this season (standard error $=83$ ind. $\mathrm{L}^{-1}$ ), but their number sharply dropped in summer $\left(12\right.$ ind. $\left.\mathrm{L}^{-1}\right)$.

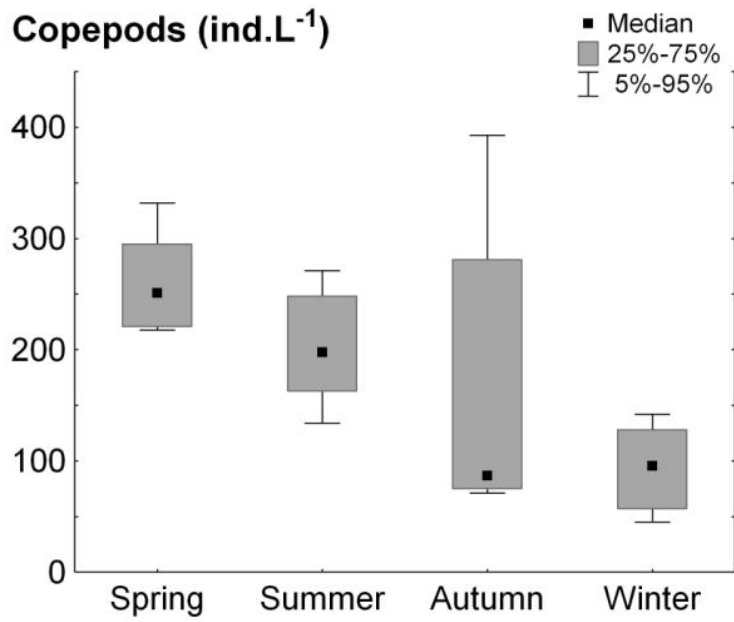

Figure 2. Seasonal features of copepods

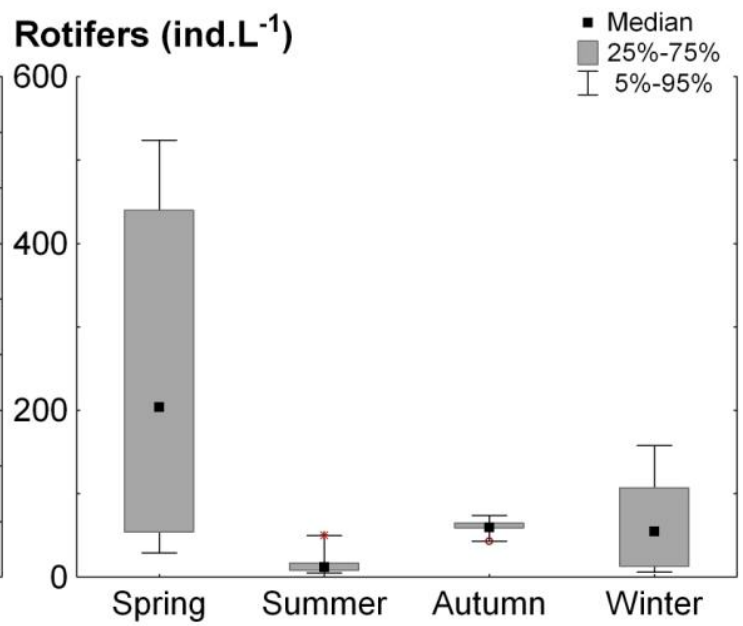

Figure 3. Seasonal features of rotifers

A total of 83 algal taxa were identified. The large spring-like richness of the phytoplankton community and its variability are highlighted (Figs. 4 and 5) and consisted of Chlorophyceae (38 species), Cyanobacteria (11), Bacillariophyceae (23), Pyrrhophyta (3), Euglenophyceae (5), Rhodophyta (1) and Charophyta (2). They contributed $33.2 \%, 33.0 \%, 26.2 \%, 6.5 \%, 0.86 \%, 0.14 \%$ and $0.09 \%$ of the total phytoplankton abundance, respectively.

\section{Phytoplancton (ind. $\mathrm{mL}^{-1}$ )}

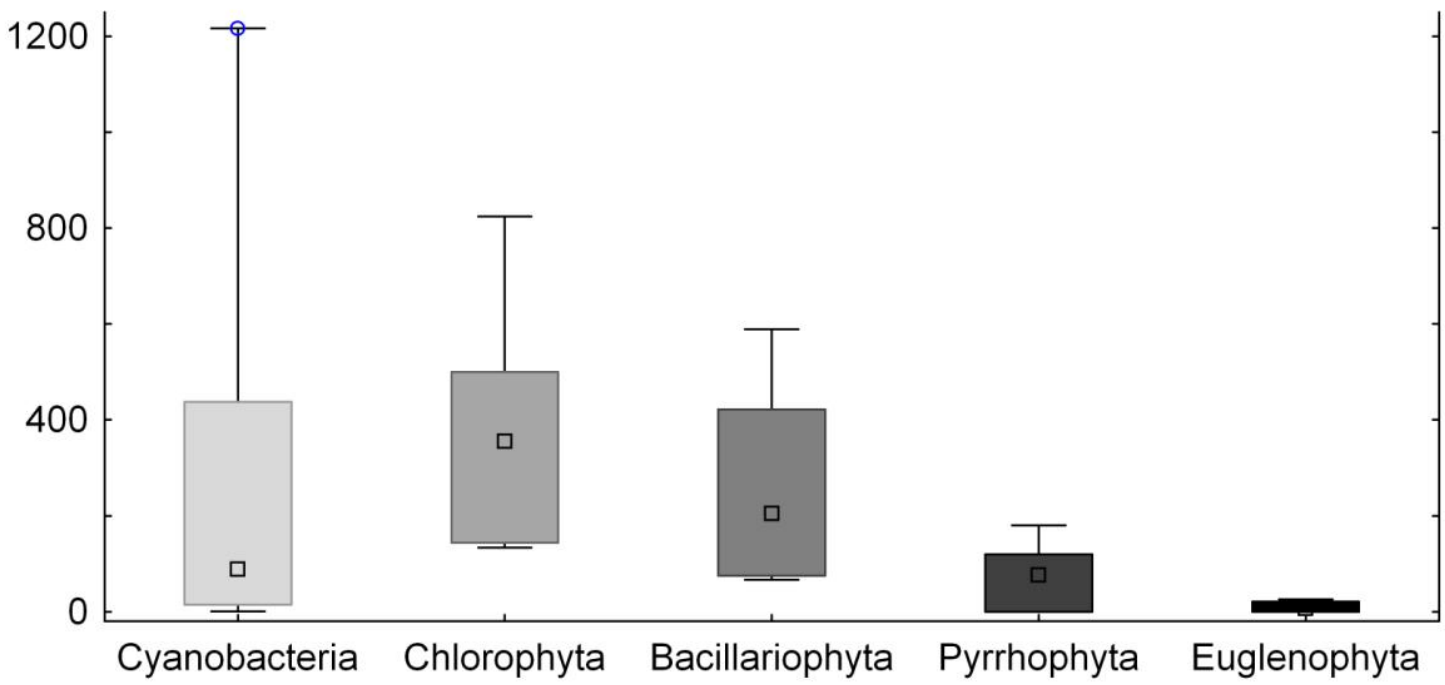

Figure 4. Distribution of the phytoplankton community ( $\square$ median, box 25-75\%, I.C. 5-95\%). 


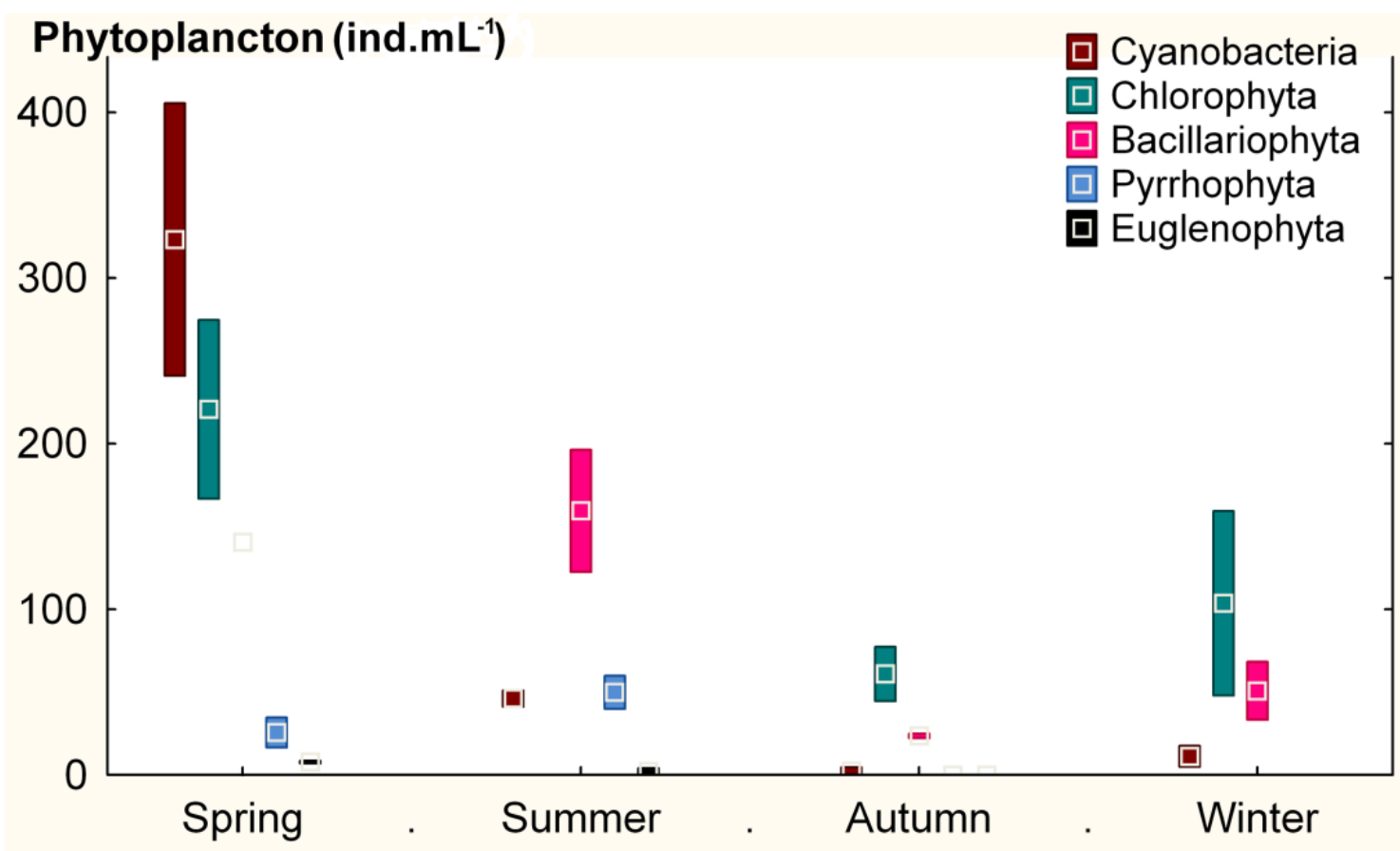

Figure 5. Seasonal features of phytoplankton ( $\square$ median, box 5-95\%).

The density of phytoplankton was distributed from the most common variety, Chlorophyta (median=118 ind. $\left.\mathrm{mL}^{-1}\right)$, to the least common one, Euglenophyta $(2.2$ ind. $\left.\mathrm{mL}^{-1}\right)$, not including Rhodophyta and Charophyta, which were not considered due to their smaller quantities.

Cyanobacteria had the greatest variability (median $=29.5$ ind. $\mathrm{mL}^{-1}$, standard error $=52.4$ ind. $\mathrm{mL}^{-1}$ ). Among the Chlorophyceae, Pediastrum simplex, Pediastrum boryanum, Chlorella sp. and Crucigeniella rectangularis were the most abundant. Among the Bacillariophyceae, Synedra acus and S. pulchella were the most abundant.

Microcystis, Oscillatoria limnetica and Microcoleus chthonoplastes were the most prevalent of the Cyanobacteria; Euglena, Lepocinclis and Phacus were the only observed genera of the Euglenophyceae. Chlorophyta represented a dominant phytoplankton division (33.2\% of total), followed by Cyanobacteria (33.0\%) and Bacillariophyta (26.2\%).

The seasonal variations of the phytoplankton are shown in Fig. 5.

Chlorophyta was most abundant in spring (average 221 ind. $\mathrm{mL}^{-1}$ ). Cyanobacteria were also at maximum density in spring (323 ind. $\mathrm{mL}^{-1}$ ) but were practically absent in autumn ( 2 to 3 ind. $\mathrm{mL}^{-1}$ ). Bacillariophyceae proliferated in July (summer average: 160 ind. $\mathrm{mL}^{-1}$ ) but fell sharply in autumn (23 to 24 ind. $\mathrm{mL}^{-1}$ ). Pyrrhophyta and, to a lesser extent, Euglenophyceae were present in spring and summer but were completely absent in autumn and winter.

\section{Weighted average of the species}

The weighted average WA(Sp) (Table 4) is the simplest way to estimate the species optimum. This method allows determining, for each species, the optimal values of the environmental variables. 
Table 4. Estimation of species optima using the weighted averages of the values of environmental variables (Cop: copepods, Rot: rotifers, Cyan: Cyanobacteria, Baci: Bacillariophyta, Pyrr: Pyrrhophyta, Eugl: Euglenophyta, Chloro: Chlorophyta, Charo: Charophyta, Rhod: Rhodophyta, Alg: algae, Org. m.: organic matter, Chl a: chlorophyll a).

\begin{tabular}{lcccccccccc}
\hline & Cop & Rot & Cyan & Baci & Pyrr & Eugl & Chloro & Charo & Rhod & Alg \\
\hline $\mathrm{T}\left({ }^{\circ} \mathrm{C}\right)$ & 21.0 & 19.6 & 21.6 & 23.0 & 25.1 & 22.4 & 18.8 & 21.0 & 16.7 & 21.3 \\
$\mathrm{pH}$ & 7.6 & 7.7 & 7.8 & 7.6 & 7.5 & 7.8 & 7.7 & 7.8 & 7.5 & 7.6 \\
$\mathrm{E} . \mathrm{C} .\left(\mathrm{mS} . \mathrm{cm}^{-1}\right)$ & 0.72 & 0.74 & 0.79 & 0.73 & 0.75 & 0.79 & 0.73 & 0.80 & 0.65 & 0.73 \\
$\mathrm{DO}(\%)$ & 88.3 & 89.6 & 92.6 & 90.2 & 93.1 & 94.2 & 84.4 & 93.1 & 77.7 & 89.0 \\
$\mathrm{NO}_{3}{ }^{-}\left(\mathrm{mg} \cdot \mathrm{L}^{-1}\right)$ & 3.82 & 4.16 & 3.93 & 4.36 & 3.16 & 4.62 & 3.90 & 3.86 & 3.41 & 3.46 \\
$\mathrm{NO}_{2}{ }^{-}\left(\mathrm{mg} \cdot \mathrm{L}^{-1}\right)$ & 0.064 & 0.079 & 0.029 & 0.075 & 0.019 & 0.027 & 0.096 & 0.020 & 0.038 & 0.083 \\
$\mathrm{SO}_{4}{ }^{2-}\left(\mathrm{mg} \cdot \mathrm{L}^{-1}\right)$ & 141.6 & 142.4 & 147.2 & 147.0 & 145.7 & 150.5 & 142.9 & 147.0 & 128.1 & 142.2 \\
$\mathrm{NH}^{+}\left(\mathrm{mg} \cdot \mathrm{L}^{-1}\right)$ & 0.035 & 0.054 & 0.040 & 0.023 & 0.033 & 0.031 & 0.033 & 0.045 & 0.012 & 0.043 \\
$\mathrm{PO}_{4}{ }^{3-}\left(\mathrm{mg} \cdot \mathrm{L}^{-1}\right)$ & 0.33 & 0.27 & 0.33 & 0.28 & 0.54 & 0.24 & 0.22 & 0.33 & 0.28 & 0.38 \\
$\mathrm{Cl}^{-}\left(\mathrm{mg} \cdot \mathrm{L}^{-1}\right)$ & 71.9 & 68.7 & 67.0 & 75.7 & 71.9 & 69.9 & 70.0 & 64.8 & 74.9 & 70.3 \\
$\mathrm{Ca}^{2+}\left(\mathrm{mg} \cdot \mathrm{L}^{-1}\right)$ & 70.2 & 72.4 & 75.0 & 68.7 & 70.2 & 74.9 & 70.8 & 76.7 & 67.5 & 70.2 \\
$\mathrm{Mg}^{2+}\left(\mathrm{mg} \cdot \mathrm{L}^{-1}\right)$ & 33.0 & 31.2 & 31.1 & 35.9 & 32.9 & 32.6 & 32.5 & 30.1 & & 32.4 \\
$\mathrm{Na}^{+}\left(\mathrm{mg} \cdot \mathrm{L}^{-1}\right)$ & 44.1 & 45.9 & 47.1 & 42.4 & 43.3 & 47.1 & 43.6 & 48.4 & 44.3 & 43.5 \\
$\mathrm{Org}^{2} \mathrm{~m}\left(\mathrm{mg} \cdot \mathrm{L}^{-1}\right)$ & 5.06 & 6.19 & 6.24 & 4.38 & 5.07 & 5.88 & 5.16 & 6.76 & 3.51 & 5.38 \\
$\mathrm{Chl}^{a}\left(\mu \mathrm{g} \cdot \mathrm{L}^{-1}\right)$ & 5.35 & 5.88 & 7.30 & 5.55 & 6.42 & 7.22 & 5.81 & 7.68 & 2.46 & 5.83
\end{tabular}

The Pyrrhophyta abundance weighted optimum was characterized by elevated temperature, DO and phosphate levels. That of Bacillariophyceae was characterized by elevated temperatures $\left(\mathrm{T}>=23.0^{\circ} \mathrm{C}\right)$, whereas Chlorophyta was generally more abundant at low temperatures $\left(\mathrm{T}<19.0^{\circ} \mathrm{C}\right)$. The prevalence of Charophyta was characterized by high optimal levels of Chl $a$ and organic matter but low levels of nitrites.

Conversely, Rhodophyta reached its optimal level at low levels of temperature, EC, Chl $a$, organic matter and ammonia. The rotifers showed their abundance-weighted optimum at high concentrations of organic matter, ammonia and nitrites.

\section{Factors regulating the seasonal dynamics of the zooplankton and phytoplankton assemblages}

A correlation matrix of environmental-species variables was produced (Table 5) to highlight the internal structure that ultimately contributes to the identification of the major sources of growth not visible at first glance.

This table highlights the strong correlations between the copepod population and the variables EC and Chl $a$. The rotifers showed a slightly significant correlation with calcium. Cyanobacteria were highly correlated with calcium, Bacillariophyta with sulfates, and Euglenophyceae with EC, calcium and Chl $a$. 
Table 5. Correlation matrix of the species-environmental variables of the Boukourdane Lake Dam waters (Cop: copepods, Rot: rotifers, Cyan: Cyanobacteria, Baci: Bacillariophyta, Pyrr: Pyrrhophyta, Eugl: Euglenophyta, Chloro: Chlorophyta, Org. m.: organic matter, Chl a: chlorophyll a). $\left({ }^{*} p<0.05 ;{ }^{* *} p<0.01 ;{ }^{* * *} p<0.001\right)$

\begin{tabular}{llllllll}
\hline & Cop & Rot & Cyan & Baci & Pyrr & Eugl & Chloro \\
\hline $\mathrm{T}$ & 0,63 & $-0,06$ & 0,24 & $0,85^{*}$ & $0,91^{*}$ & 0,15 & 0,72 \\
$\mathrm{pH}$ & 0,24 & 0,53 & 0,48 & 0,19 & $-0,25$ & 0,75 & 0,44 \\
$\mathrm{EC}$ & $\mathbf{0 , 9 1}{ }^{* *}$ & 0,54 & $0,75^{*}$ & $0,81^{*}$ & 0,36 & $\mathbf{0 , 9 2}{ }^{* *}$ & 0,79 \\
$\mathrm{DO}$ & 0,44 & 0,27 & 0,34 & 0,53 & 0,55 & 0,54 & 0,09 \\
$\mathrm{NO}_{3}{ }^{-}$ & 0,11 & 0,19 & 0,06 & 0,25 & $-0,20$ & 0,39 & 0,05 \\
$\mathrm{NO}_{2}{ }^{-}$ & $-0,80^{*}$ & $-0,16$ & $-0,38$ & $-0,39$ & $-0,64$ & $-0,06$ & $-0,32$ \\
$\mathrm{SO}_{4}{ }^{2-}$ & 0,65 & 0,31 & 0,47 & $\mathbf{0 , 8 8 * *}$ & 0,35 & 0,64 & $0,87^{*}$ \\
$\mathrm{NH}_{4}{ }^{+}$ & $-0,42$ & 0,20 & $-0,04$ & $-0,38$ & 0,42 & 0,27 & $-0,42$ \\
$\mathrm{PO}_{4}{ }^{3-}$ & 0,11 & $-0,13$ & 0,02 & $-0,04$ & 0,50 & $-0,35$ & $-0,09$ \\
$\mathrm{Na}^{+}$ & 0,53 & 0,54 & 0,51 & 0,07 & $-0,13$ & 0,54 & $-0,03$ \\
$\mathrm{Cl}^{-}$ & $-0,10$ & $-0,59$ & $-0,56$ & 0,58 & $-0,17$ & $-0,41$ & $-0,16$ \\
$\mathrm{Ca}^{2+}$ & $0,81^{*}$ & $0,79^{*}$ & $\mathbf{0 , 8 7}{ }^{* *}$ & 0,52 & $-0,02$ & $\mathbf{0 , 9 2}{ }^{* *}$ & 0,49 \\
$\mathrm{Mg}^{2+}$ & $-0,52$ & $-0,56$ & $-0,63$ & 0,94 & $-0,23$ & $-0,24$ & 1,00 \\
$\mathrm{Org} \mathrm{m}$ & $-0,02$ & 0,56 & 0,38 & $-0,21$ & 0,31 & 0,77 & $-0,14$ \\
$\mathrm{Chl} a$ & $\mathbf{0 , 8 1}{ }^{*}$ & 0,55 & $0,80^{*}$ & $0,82^{*}$ & 0,60 & $\mathbf{0 , 8 4}$ & $0,90^{*}$ \\
\hline
\end{tabular}

\section{RDA analysis}

The redundancy analysis (RDA) was applied to 15 environmental variables and 10 species variables, which were reduced to 11 and 7 variables, respectively, in the final RDA (Figs. $6 A$ and $6 B$ ). The large number of variables required to efficiently diagnose the water quality is an obstacle to the implementation of a coherent and sustainable monitoring program. Therefore, certain variables were omitted, due to insufficient collected data or errors.
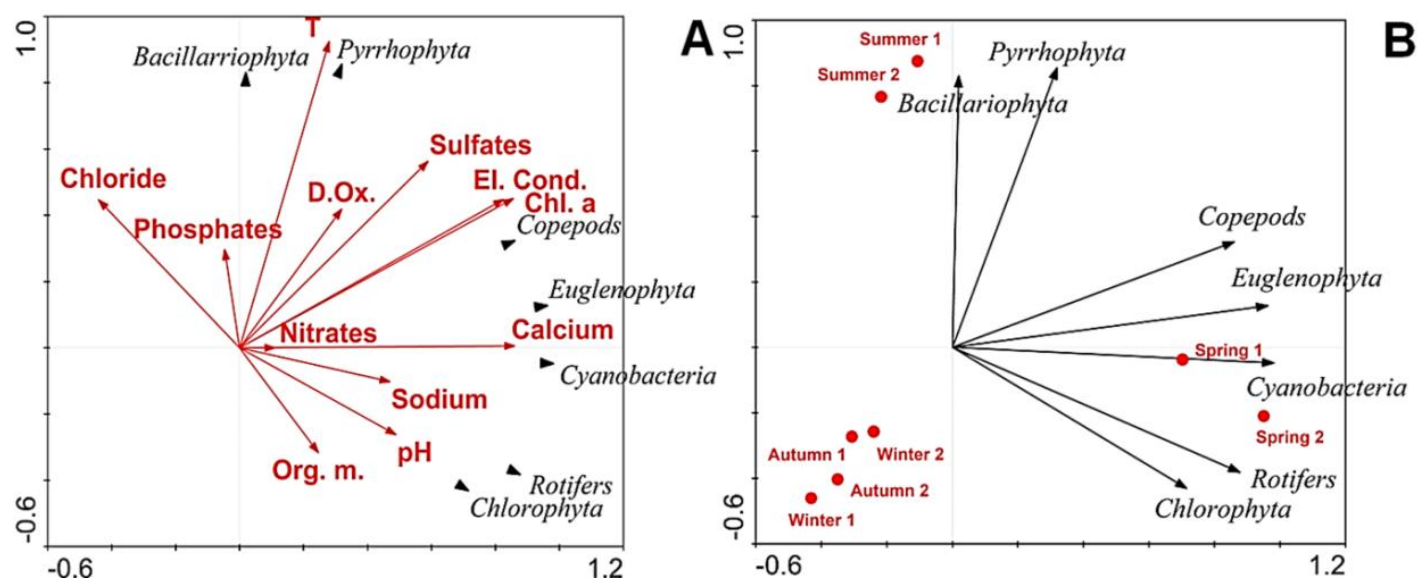

Figure 6. Biplot in the redundancy analysis (RDA) of zooplankton and phytoplankton species in relation to environmental scores. 
The RDA biplot of the plankton species and the environmental scores corroborate our previous observations. The first two axes explain $84.1 \%$ of the data variance, which is a satisfactory percentage. Most of the taxa appear on the right side of the factorial graph, corresponding mostly to the spring and related to "intermediate to high" levels of mineral content or trophic state.

The zooplankton and a large part of the phytoplankton abundance were quite sharply influenced by the levels of sulfates, EC, Chl $a$ and calcium. This effect was lower for dissolved oxygen, sodium and nitrates. Rotifers and Chlorophyta appeared to be more influenced by $\mathrm{pH}$ variability, sodium and organic matter contents. Bacillariophyta and Pyrrhophyta appeared in summer and were influenced by elevated temperatures.

\section{Discussion}

\section{Physico-chemical variables and Pearson's correlations}

The $\mathrm{pH}$ values classify Boukourdane Lake Dam in the quasi-alkaline range (6.3-8.1), which is indicative of the medium production and alkaliphilous water body category under the criteria of Venkateswarlu (1983). The observed fluctuations in the electrical conductivity could be due to variations in the decomposition rate of organic matter, the low level of water caused by evaporation, or the influx of seepage and nutrients from the drainage basin. This reservoir can be classified as eutrophic according to the Olsen criteria (1950) (conductivity $>500 \mu \mathrm{S} . \mathrm{cm}^{-1}$ ).

In general, the solubility of oxygen decreases when the temperature and salinity increase. Throughout the study period, the dissolved oxygen level was generally close to saturation in summer and spring. The relatively low levels in autumn may be due to pollution in the site or to decaying algal cells that used up the available dissolved oxygen at the water surface. These results were identical to those reported by Shah and Pandit (2013).

A high concentration of nitrates, as observed in spring and winter, is useful in irrigation, but their entry into water resources increases the growth of nuisance algae and triggers eutrophication and pollution (Trivedy and Goel, 1984). This could also be due to the high level of dissolved oxygen during these periods. In winter, the high levels of nitrites might be partly due to influx of nutrients from the watershed areas along with the runoff water in this cold period. Using Pearson's correlation, Yu et al. (2014) suggest a strong and positive correlation between toxicity and the total nitrogen in wastewater, including $\mathrm{NO}_{2}{ }^{-}$and $\mathrm{NH}_{4}{ }^{+}$. The pattern of nitrite-nitrogen concentration was found to be quite similar to that observed by Garg et al. (2010) and Sulthana et al. (2011).

The actual level of phosphates defines the Boukourdane reservoir as a eutrophic water body (Lee et al., 1981). Based on the total phosphorus level, Tammeorg et al. (2014) found a similar evolution, with the highest values during late summer and early autumn and the lowest during the winter and spring periods in different lakes. The very high levels (>30) of the $\mathrm{NO}_{3}-/ \mathrm{PO}_{4}{ }^{3-}$ ratio are related to the poverty of plankton in winter and are in agreement with the results of Herut et al. (2000). A ratio of 20:1 suggests that the algae may be phosphorus-limited, which is typical for most freshwater systems (Sargeant, 1997).

The high concentrations of sodium limit the biological diversity due to osmotic stress; the encountered levels are consistent with the findings of Mathur et al. (2010) and Usharani et al. (2010). The slightly higher levels of chloride in summer and autumn 
may be attributed to the rise in temperature increasing the rate of evaporation, causing a decline in water cover. These results are in accordance with the reports of Govindasamy et al. (2000) and Moundiotiya et al. (2004). Under the classification of Unni (1983), this reservoir can be categorized as a polluted water body.

The magnesium level, which is essential for chlorophyll growth (Dagaonkar and Saksena, 1992), remained under standard values but could not be measured during autumn and winter.

The chlorophyll in an aquatic body is a direct indication of algal growth. According to the OECD criteria (1982), its concentration was practically in the mesotrophic range (2.5-8.0 $\left.\mu \mathrm{g} . \mathrm{L}^{-1}\right)$.

A correlations analysis highlighted significant relationships between land use types and water quality during the dry and rainy seasons in a basin ( $\mathrm{Bu}$ et al., 2014). The correlation analysis in another lake showed that a select number of macroinvertebrate metrics were significantly correlated with environmental variables (Johnson and Ringler, 2014). These relationships have been essentially confirmed in this work for EC correlated to copepod abundance, and for EC, sulfates and calcium correlated with a part of the phytoplankton.

\section{Seasonal richness of copepods, rotifers and phytoplankton}

The principal species found in the Boukourdane Lake Dam were consistent with those described by other studies performed on the Algerian aquatic ecosystem (Samraoui et al., 1998; Cherbi et al., 2008; Bouzidi et al., 2010; Hamaidi et al., 2010; Hamaidi-Chergui et al., 2013). The rotifer results are consistent with those of Zanata and Espindola (2002), who found them to be dominant during the dry period. Sartori et al. (2009) and other studies showed that rotifers are always the species with the highest richness.

Because the physico-chemical variables change throughout the year, it is of considerable interest to quantify the seasonal changes in the zooplankton community structure (Enriquez Garcia et al., 2009), and in reservoirs used for water supply, this knowledge can be important for quality management purposes (Garcia et al., 2002).

Polyarthra remata was mostly present in winter, which is in agreement with Cherbi et al. (2008). Keratella species are inhabitants of moderately clean (mesotrophic) waters (Saksena, 1986). Generally, Keratella quadrata and Filinia longiseta are indicators of eutrophic lakes (Geng et al., 2005).

Many rotifer species occurred sporadically, and most of them were found only in the littoral zone. It is known that inorganic nitrogen such as $\mathrm{NO}_{3}{ }^{-}$and $\mathrm{NO}_{2}{ }^{-}$can help increase the rotifer density, for which an important determinant is the trophic status of lakes (Wang et al., 2010). The oligotrophication in a lake may coincide with decreases in Polyarthra or Keratella (Barbiero and Warren, 2011). Hexarthra fennica, present in summer, is described as euryhaline and seasonal.

The high copepod density in spring was correlated with elevated levels of Chl $a$. The most common species were Copidodiaptomus numidicus and Acanthocyclops trajani, as found in earlier studies (Cherbi et al., 2008). In general, an adequate food supply in terms of a high Chl $a$ concentration favours the copepods, which feed more selectively (Voutilainen et al., 2012). Chl $a$ had a greater impact on species common in the open water than on macrophytes (Enriquez Garcia et al., 2009).

In general, the phytoplankton level is a useful tool for assessing long-term changes in rivers, such as those associated with eutrophication and river management (Prygiel et al., 1999). The abundance of the spring species Chlorophyta is consistent with the 
results reported by Yerli et al. (2012) and Yilmaz and Aykulu (2010). Van den Hoeck et al. (1995) already showed that Chlorophyceae are a large and important group of freshwater algae.

The high rates of productivity encountered during spring can be due to the increase in temperature and the high transparency, speeding up the photosynthetic activity of the phytoplankton (Bhoyar and Tamloorkar, 2012). Moreover, the excess nutrients can cause algal blooms and the possibility of water contamination by toxin producers, if present (Marcé et al., 2010).

The weighted averages of the species were very useful and enabled us to develop an estimated mapping of species for any dataset of environmental variables, which is very helpful for preventive monitoring.

\section{RDA analysis}

Multivariate statistical techniques help in the interpretation of complex data matrices to better understand the water quality and ecological status of the systems studied (Shrestha and Kazama, 2007). These techniques have been applied to evaluate the temporal or spatial variations of water quality data and also their usefulness to obtain better information for the effective management of water resources (Singh et al., 2004).

The RDA analysis corroborated a great part of the previous results reported in this work. A low contribution of relationships between some environmental variables and copepod assemblages has been found (Fiasca et al, 2014), corroborating our results for dissolved oxygen, $\mathrm{pH}$ and nitrates. The strong presence of Chlorophyta in the spring, which correlated with the $\mathrm{pH}$ and the organic matter density, is also in agreement with the results of O'Farell et al. (2002) who noted that the profuse phytoplankton growth led to increases in the $\mathrm{pH}$ and suspended matter content.

\section{Conclusions}

In conclusion, the Boukourdane Lake Dam can be categorized as eutrophic according to its levels of EC, phosphates and Chl $a$ but stands at an intermediate position when compared to other temperate water bodies.

The redundancy analysis revealed that sulfates, EC, Chl $a$ and calcium were the most important variables affecting the zooplankton and phytoplankton distribution. Great variability in the levels of nitrites, nitrates, phosphates and ammonia was observed from one season to another.

The values of the environmental parameters for each species optimum were determined through calculation of their weighted averages. This allowed us to fairly accurately determine the distribution of the most prevalent species for every season.

The results confirmed earlier findings stipulating that the Boukourdane reservoir was dominated by rotifer species, but in spite of their lower number and predation from vertebrates, the crustacean zooplankton were more numerically abundant, especially in the spring.

This pilot investigation suggests that more studies are necessary in Algerian lakes to improve our knowledge of zooplankton and phytoplankton distributions, composition and relationships with the water quality, so this report represents the beginning of studies on environmental conditions. 
The present study offers a significant base to evaluate the fish production potentialities and to formulate sustainable management policies for aquaculture in the study area.

Acknowledgments. We express our gratitude to Dr Danielle Defaye from "Département Milieux et Peuplements Aquatiques, Muséum National d'Histoire Naturelle", Paris, France, for access to laboratory facilities and to "Agence Nationale des Ressources Hydriques de Soumaâ" (ANRH, Algérie) for providing technical support during this study.

\section{REFERENCES}

[1] Al-Ghanim, K.A. (2012): Spatio-Temporal Distribution and Composition of Zooplankton in Wadi Hanifah Stream Riyadh (Saudi Arabia) and Abu Zabaal Lakes (Egypt). - Pakistan Journal of Zoology 44: 727-736.

[2] Anagnostidis, K., Komarek, J. (1988, 1990): Modern approach to the classification system of Cyanophytes, 3, Oscillatoriales. - Algological Studies/Archiv für Hydrobiologie, Supplement vol. 50-53: 327-472, 5 Stigonematales. Supplement vol. 59: 1-73.

[3] APHA (1998): Standard Methods for the Examination of Water and Waste water. - American Public Health Association, 18th ed., Washington DC, USA.

[4] Barbiero, R.P., Warren, G.J. (2011): Rotifer communities in the Laurentian Great Lakes, 1983-2006 and factors affecting their composition. - Journal of Great Lakes Research 37: 528-540.

[5] Beaugrand, G., Ibanez, F., Reid, P.C. (2000): Spatial, seasonal and long-term fluctuations of plankton in relation to hydroclimatic features in the English Channel, Celtic Sea and Bay of Biscay. - Marine Ecology Progress Series 200: 93-102.

[6] Bhoyar, V.V., Tamloorkar, H.L. (2012): Seasonal variations in phytoplankton abundance of Ambona lake Maharashtra. - International Multidisciplinary Research Journal 2: 33-35.

[7] Bourelly, P. (1966, 1968, 1970): Les algues d'eau douce. Initiation à la systématique. Tome I, II and III. - Eds. Boubée et Cie, Paris.

[8] Bouzidi, M.A., Amar, Y., Attaoui, I., Latreche, A., Benyahia, M., Bouguenaya, N., Meliani, H. (2010): Copépodes, Cladocères et Rotifères du lac Sidi M'hamed Benali Algérie Nord-Occidentale. - Physio-Géo, Géographie Physique et Environnement 4: 69-85.

[9] Brainwood, M.A., Burgin, S., Maheshwari, B. (2004): Temporal variations in water quality of farm dams: impacts of land use and water sources. - Agricultural Water Management 70: 151-175.

[10] Bu, H., Meng, W., Zhang, Y., Wan, J. (2014): Relationships between land use patterns and water quality in the Taizi River basin, China. - Ecological Indicators 41: 187-197.

[11] Chaib, N., Alfarhan, A.H., Al-Rasheid, K.A.S., Samraoui, B. (2011): Environmental determinants of diatom assemblages along a North African wadi, the Kebir-East, North-East Algeria. - Journal of Limnology 70: 33-40.

[12] Cherbi, M., Lek-Ang, S., Lek, S., Arab, A. (2008): Distribution du zooplancton dans les lacs à climat méditerranéen. - Comptes Rendus Biologies 331: 692-702. 
[13] Compere, P. (1974, 1975a, 1975b, 1977): Algues de la région du lac Tchad, II, III, IV and VII. - Série Hydrobiologie 8: 165-198; 9: 167-192; 9: 203-290; 11: 135164.

[14] Compere, P. (1991, 1992, 2001): Flore pratique des algues d'eau douce de Belgique, Tomes 3, 4 et 5. - Jardin Botanique National de Belgique, Meise.

[15] Dagaonkar, A., Saksena, D.N. (1992): Physico-chemical and Biological characterization of a temple tank, Kaila Sagar, Gwalior, Madhya Pradesh. Journal of Hydrobiology 8: 11-19.

[16] Dussart, B., Defaye, D. (1985): Répertoire mondial des copépodes cyclopoïdes. Ed. CNRS, Paris.

[17] Dussart, B., Defaye, D. (2001): Introduction to the Copepoda. - In: Dumont, Guides to the Identification of the Microinvertebrates of the Continental Waters of the World, H.J.F. (Eds.) 16:1-344, Backhuys Publishers, Leiden.

[18] Einsle, U. (1996): Copepoda: Cyclopoida, Genera Cyclops, Megacyclops, Acanthocyclops. - In: Dumont, Guides to the Identification of the Microinvertebrates of the Continental Waters of the World, H.J.F. (Eds.) 10: 183, Backhuys Publishers, Leiden.

[19] Elmaci, A., Topac, F.O., Ozengin, N., Teksoy, A., Kurtoglu, S., Baskaya, H.S. (2008): Evaluation of physical, chemical and microbiological properties of lake Uluabat, Turkey. - Journal of Environmental Biology 29: 205-210.

[20] Enriquez Garcia, C., Nandini, S., Sarma, S.S.S. (2009): Seasonal dynamics of zooplankton in Lake Huetzalin, Xochimilco (Mexico City, Mexico). Limnologica 39: 283-291.

[21] Fiasca, F., Stoch, F., Olivier, M.J., Maazouzi, C., Pettita, M., Di Cioccio, A., Galassi, D.M.P. (2014): The dark side of springs: what drives small-scale spatial patterns of subsurface meiofaunal assemblages? - Journal of Limnology 73: 5564.

[22] Garcia, P.R., Nandini, S., Sarma, S.S.S., Valderrama, E.R., Cuesta, I., Hurtado, M.D. (2002): Seasonal variations of zooplankton abundance in the freshwater reservoir Valle de Bravo (Mexico). - Hydrobiologia 467: 99-108. - In: Sartori, L.P., Nogueira, M.G., Henry, R., Moretto, E.M. (2009): Zooplankton fluctuations in Jurumirim Reservoir (São Paulo, Brazil): a three-year study. - Brazilian Journal of Biology 69: 1-18.

[23] Garg, R.K., Rao, R.J., Uchchariya, D., Shukla, G., Saksena, D.N. (2010): Seasonal variations in water quality and major threats to Ramsagar reservoir, India. - African Journal of Environmental Science and Technology 4: 61-76.

[24] Geng, H., Xie, P., Deng, D., Zhou, Q. (2005): The rotifer assemblage in a shallow. Eutrphic Chinese Lake and its relationships with cyanobacterial blooms and crustacean zooplankton. - Journal of Freshwater Ecology 20: 93-100. - In: Apaydin Yağci, M. (2013): Seasonal zooplankton community variation in Karatas Lake, Turkey. - Iranian Journal of Fisheries Sciences 12: 265-276.

[25] Govindasamy, C., Kannan, L., Azariah, J. (2000): Seasonal variation in physicochemical properties and primary production in the coastal water biotopes of Coromandel coast, India. - Journal of Environmental Biology 21: 1-7.

[26] Hamaidi, F., Defaye, D., Semroud, R. (2010): Copepoda of Algerian fresh waters: checklist, new records, and comments on their biodiversity. - Crustaceana 83: $101-126$. 
[27] Hamaidi, F., Hamaidi, M.S., Guetarni, D., Saidi, F., Mohamed Said, R. (2008): Rotifères de l'Oued Chiffa (Algérie). - Bulletin de l'Institut Scientifique de Rabat, section Sciences de la Vie 30: 19-27.

[28] Hamaidi, M.S., Hamaidi, F., Zoubiri, A., Benouaklil, F., Dhan, Y. (2009): Etude de la dynamique des populations phytoplanctoniques et résultats préliminaires sur les blooms toxiques à Cyanobactéries dans le barrage de Ghrib (Ain DeflaAlgérie). - European Journal of Scientific Research 32: 369-380.

[29] Hamaidi-Chergui, F., Hamaidi, M.S. (2013): A Preliminary Survey on Abiotic Parameters and Phytoplanktonic Algae of Keddara Dam Lake (Boumerdes-North East Algeria). - Journal of Applied Phytotechnology in Environmental Sanitation 2: 115-120.

[30] Hamaidi-Chergui, F., Hamaidi, M.S., Brahim Errahmani, M., Benouaklil, F. (2013): Studies on biodiversity of Rotifera in five artificial lakes in Algeria: Systematical and Zoogeographical remarks. - Kragujevac Journal of Sciences 35: 115-138.

[31] Herut, B., Almogi-Labin, A., Jannink, N., Gertman, I. (2000): The seasonal dynamics of nutrient and chlorophyll $a$ concentrations on the SE Mediterranean shelf-slope. - Oceanologica Acta 23: 771-782.

[32] Johnson, S.L., Ringler, N.H. (2014): The response of fish and macroinvertebrate assemblages to multiple stressors: A comparative analysis of aquatic communities in a perturbed watershed (Onondaga Lake, NY). - Ecological Indicators 41: 19820.

[33] Karaytug, S. (1999): Copepoda: Cyclopoida, Genera Paracyclops, Ochridacyclops and key to the Eucyclopinae. - In: Dumont, Guides to the Identification of the Microinvertebrates of the Continental Waters of the World, H.J.F. (Eds.) 14: 1127, Backhuys Publishers, Leiden.

[34] Komarek, J., Anagnostidis, K. (1986, 1989): Modern approach to the classification system of Cyanophytes. - 2, 4 Algological Studies/Archiv für Hydrobiologie 43: 157-226; 56: 247-345.

[35] Lee, G.F., Jones, R.A., Rast, W. (1981): Alternative approach to trophic state classification for water quality management, Occasional Paper $\mathrm{n}^{\circ} 66$, Dept. of Civ. Env. Eng. Prog. - Colorado State University, Fort Collins, Colorado.

[36] Leps, J., Smilauer, P. (2003): Multivariate analysis of ecological data using CANOCO. - Cambridge University Press. (www.cambridge.org/9780521814096)

[37] Marcé, R., Moreno-Ostos, E., Garcia-Barcina, J.M., Armengol, J. (2010): Tailoring dam structures to water quality predictions in new reservoir projects: Assisting decision-making using numerical modelling. - Journal of Environmental Management 91: 1255-1267.

[38] Mathur, P., Patan, S., Sharma, K., Nair, N., Shobhawat, A. (2010): Assessment of physico-chemical properties of Anasagar Lake of Ajmer (India). - Journal of Environmental Research and Development 4: 780-787.

[39] McCartney, M.P., Sullivan, C., Acreman, M.C. (2001): Ecosystem Impacts of Large Dams, Background Paper $n^{\circ}$ 2, prepared for IUCN/UNEP/WCD. - United Nations Foundation.

[40] Moundiotiya, C., Sisodia, R., Kulshreshtha, M., Bhatia, A.L. (2004): A case study of the Jamwa Ramgarh wetland with special reference to physical and chemical properties of water and its environs. - Journal of Environmental Hydrology 12: 17. 
[41] Nogrady, T., Wallace, R.L., Snell, T.W. (1993): Rotifera 1, Biology, ecology and systematics. - In: Dumont, Guides to the identification of the microinvertebrates of the continental waters of the world, H.J. (Eds.), SPB Academic Publishing BV, The Hague.

[42] O’Farell, I., Lombardo, R.J., de Tezanos Pinto, P., Loez, C. (2002): The assessment of water quality in the Lower Lujan River (Buenos Aires, Argentina): phytoplankton and algal bioassays. - Environmental Pollution 120: 207-218.

[43] OECD (1982): Eutrophication of water monitoring, assessment and control. OECD, Paris.

[44] Olsen, S. (1950): Aquatic plants and hydrospheric factors 1, aquatic plants in SW Jutland. - Denmark Svensk Botanisk Tidskrift 44: 1-34.

[45] Pilière A., Schipper A.M., Breure A.M., Posthuma L., de Zwart D., Dyerc S.D., Huijbregts M.A.J. (2014): Comparing responses of freshwater fish and invertebrate community integrity along multiple environmental gradients. Ecological Indicators, 43: 215-226.

[46] Pourriot, R., Francez, A.J. (1986): Rotifères, Introduction pratique à la systématique des organismes des eaux continentales françaises. - Bulletin Mensuel de la Société Linnéenne de Lyon 8: 1-37.

[47] Prygiel, J., Whitton, B.A., Bukowska, J. (1999): Use of Algae for monitoring rivers III. - Proceedings of an international symposium, Douai, France, 1999. In: O'Farell, I., Lombardo, R.J., de Tezanos Pinto, P., Loez, C. (2002): The assessment of water quality in the Lower Lujan River (Buenos Aires, Argentina): phytoplankton and algal bioassays. - Environmental Pollution 120: 207-218.

[48] Ramdani, A., Djellouli, H.M., Aït Yala, N., Taleb, S., Benghalem, A., Mahi, C., Khadraoui, A. (2012): Physico-Chemical Water Quality in Some Regions of Southern Algeria and Pretreatment Prediction. - Procedia Engineering 33: 335339.

[49] Rodier, J. (1997): L'Analyse de l'Eau: Eaux Naturelles, Eaux Résiduaires, Eau de Mer, 8th ed. - Dunod, Paris, France.

[50] Saksena, D.N. (1986): Rotifers as Indicators of Water Quality. - Acta Hydrobiologica 15: 481-485. - In: Apaydin Yağci, M. (2013). Seasonal zooplankton community variation in Karatas Lake, Turkey. - Iranian Journal of Fisheries Sciences 12: 265-276.

[51] Samraoui, B., Segers, H., Maas, S., Baribwegure, D., Dumont, H.D. (1998): Rotifera, Cladocera, Copepoda, and Ostracoda from coastal wetlands in northeast Algeria. - Hydrobiologia 386: 183-193.

[52] Sargeant, D. (1997): Water quality in the Wapato Basin of Lake Chelan, Summer 1996. - Ecology Report 97-223. Waterbody No. WA-47-9020, Washington State Department of Ecology.

[53] Sartori, L.P., Nogueira, M.G., Henry, R., Moretto, E.M. (2009): Zooplankton fluctuations in Jurumirim Reservoir (São Paulo, Brazil): a three-year study. Brazilian Journal of Biology 69: 1-18.

[54] Shah, J.A., Pandit, A.K. (2013): Relation between physico-chemical limnology and crustacean community in Wular Lake of Kashmir Himalaya. - Pakistan Journal of Biological Sciences 16: 976-983.

[55] Shrestha, S., Kazama, F. (2007): Assessment of surface water quality using multivariate statistical techniques: A case study of the Fuji river basin, Japan. Environmental Modelling \& Software 22: 464-475. 
[56] Singh, K.P., Malik, A., Mohan, D., Sinha, S. (2004): Multivariate statistical techniques for the evaluation of spatial and temporal variations in water quality of Gomti River (India): a case study. - Water Research 38: 3980-3992.

[57] Sournia, A. (1968): La Cyanophycée Oscillatoria dans le plancton marin: taxinomie, et observations dans le Canal de Mozarnbique. - Nova Hedwigia 15: $1-12$.

[58] Sulthana, M., Vasanthi, R., Jayaprakash, J.N. (2011): Hydrochemistry and seasonal fluctuation of plankton in Arasankulam pond at Veppampattu in Thiruvallur, District of Tamil Nadu, India. - Nature Environment and Pollution Technology 10: 467-470.

[59] Tammerog, O., Möls, T., Kangur, K. (2014): Weather conditions influencing phosphorus concentration in the growing period in the large shallow lake Peipsi (Estonia/Russia). - Journal of Limnology 73: 11-19.

[60] Telesh, I.V. (2004): Plankton of the Baltic estuarine ecosystems with emphasis on Neva Estuary: a review of present knowledge and research perspectives. - Marine Pollution Bulletin 49: 206-219.

[61] ter Braak, C.J.F., Smilauer, P. (2002): CANOCO Reference Manual and CanoDraw for Windows, User's Guide: Software for Canonical Community Ordination (version 4.5). - Microcomputer Power, Ithaca N.Y., U.S.A.

[62] Trivedy, R.K., Goel, P.K. (1984): Chemical and Biological Methods for Water Pollution Studies. - Environmental Publications, Karad, India.

[63] Unni, K.S. (1983): Comparative water chemistry of a plankton dominated and macrophytes dominated lake in Chhindwara, M.P. - Proceedings of the National Academy of Sciences, India 53: 81-88.

[64] Usharani, K., Umarani, K., Ayyasamy, P.M., Shanthi, K., Lakshmanaperumalsamy, P. (2010): Physico-Chemical and Bacteriological Characteristics of Noyyal River and Ground Water Quality of Perur, India. Journal of Applied Sciences and Environmental Management 14: 29-35.

[65] Van Den Hoek, C., Mann, D., Jahns, H.M. (1995): Algae: An introduction to phycology. - Cambridge University Press, Cambridge.

[66] Venkatesan, J. (2007): Protecting Wetlands. - Current Science 93: 288-290.

[67] Venkateswarlu, V. (1983): Taxonomy and ecology of algae in the river Moosi, Hyderabad, India, II, Bacillariophyceae, Algae of the Indian subcontinent. Bibliothecae Phycologica 66: 1-141.

[68] Voutilainen, A., Rahkola-Sorsa, M., Parviainen, J., Huttunen, M.J., Viljanen, M. (2012): Analysing a large dataset on long-term monitoring of water quality and plankton with the SOM clustering. - Knowledge and Management of Aquatic Ecosystems 406: 04.

[69] Wang, S., Xie, P., Geng, H. (2010): The relative importance of physicochemical factors and crustacean zooplankton as determinants of rotifer density and species distribution in lakes adjacent to the Yangtze River, China. - Limnologica 40: 1-7.

[70] Yerli, S.V., Kivrak, E., Gürbüz, H., Manav, E., Mangit, F., Türkecan, O. (2012): Phytoplankton community, nutrients and chlorophyll $a$ in Lake Mogan (Turkey), with comparison between current and old data. - Turkish Journal of Fisheries and Aquatic Sciences 12: 95-104.

[71] Yilmaz, N., Aykulu, G. (2010): An investigation on the seasonal variation of the phytoplankton density on the surface water of Sapanca Lake, Turkey. - Pakistan Journal of Botany 42: 1213-1224. 
[72] Yu, X., Zuo, J., Li, R., Gan, L., Li, Z., Zhang, F. (2014): A combined evaluation of the characteristics and acute toxicity of antibiotic wastewater. - Ecotoxicology and Environmental Safety 106: 40-45.

[73] Zanata, L.H., Espindola, E.L.G. (2002): Longitudinal processes in Salto Grande Reservoir (Americana, SP,Brazil) and its influence in the formation of compartment system. - Brazilian Journal of Biology 62: 347-361. 